\title{
Legal institutionalism: Capitalism and the constitutive role of law
}

\author{
Simon Deakin ${ }^{\mathrm{a}}$, David Gindis ${ }^{\mathrm{b}}$, Geoffrey M. Hodgson ${ }^{\mathrm{b}, *}$, Kainan Huang ${ }^{\mathrm{c}}$, \\ Katharina Pistor ${ }^{\mathrm{d}}$ \\ a Faculty of Law, University of Cambridge, UK \\ ${ }^{\mathrm{b}}$ Hertfordshire Business School, University of Hertfordshire, UK \\ ' Shandong University, China \\ ${ }^{\mathrm{d}}$ Columbia Law School, USA
}

\section{A R T I C L E I N F O}

\section{Article history:}

Available online 11 April 2016

\section{Keywords:}

Institutions

Law

Capitalism

Theory of the firm

Property rights

\begin{abstract}
A B S T R A C T
Deakin, Simon, Gindis, David, Hodgson, Geoffrey M., Huang, Kainan, and Pistor, Katharina-Legal institutionalism: Capitalism and the constitutive role of law

Social scientists have paid insufficient attention to the role of law in constituting the economic institutions of capitalism. Part of this neglect emanates for inadequate conceptions of the nature of law itself. Spontaneous conceptions of law and property rights that downplay the role of the state are criticized here, because they typically assume relatively small numbers of agents and underplay the complexity and uncertainty in developed capitalist systems. In developed capitalist economies, law is sustained through interaction between private agents, courts and the legislative apparatus. Law is also a key institution for overcoming contracting uncertainties. It is furthermore a part of the power structure of society, and a major means by which power is exercised. This argument is illustrated by considering institutions such as property and the firm. Complex systems of law have played a crucial role in capitalist development and are also vital for developing economies. Journal of Comparative Economics 45 (2017) 188-200. Faculty of Law, University of Cambridge, UK; Hertfordshire Business School, University of Hertfordshire, UK; Shandong University, China; Columbia Law School, USA.
\end{abstract}

(c) 2016 Association for Comparative Economic Studies. Published by Elsevier Inc. This is an open access article under the CC BY license.

(http://creativecommons.org/licenses/by/4.0/)

At this early stage of its development, legal institutionalism ${ }^{1}$ involves claims concerning the nature of social reality, at least in modern, developed socio-economic systems. It does not yet provide a full theoretical approach, but it does provide some tentative and limited indications concerning theory and policy.

There are two primary ontological claims. The first concerns the nature of law. It is argued that law (at least in the fullest and most developed sense) necessarily involves both the state (broadly construed to refer to a realm of public ordering) and private or customary arrangements. Reduction of law to just one of these two aspects is mistaken. As well as drawing from custom, law involves an institutionalized judiciary and a legislative apparatus.

\footnotetext{
* Corresponding author.

E-mail address: g.m.hodgson@herts.ac.uk (G.M. Hodgson).

1 The term "legal institutionalism" has been used by some legal scholars to refer to institution-orientated theories of law (La Torre 1993, MacCormick 2007). We use it to denote legally-grounded approaches to the institutional and economic analysis of capitalism, as in the cases of Commons (1924) and Samuels (1989).
} 
The second ontological claim is that law - understood as an outcome of both state intervention and private ordering accounts for many of the rules and structures of modern capitalist society. Consequently, law is not simply an expression of power relations, but is also a constitutive part of the institutionalized power structure, and a major means through which power is exercised. This claim applies primarily to modern developed capitalist economies. Underdeveloped societies, where the rule of law is compromised by a degree of arbitrary power, may depend even more on propaganda and coercion, and less on the operation of legal rules. But even in these cases, at least in the modern world, law still plays an important role.

Models of the spontaneous development of law typically rest on relatively small numbers of agents and underestimate the complexities and uncertainties in developed capitalism. The law made by organs of the state, including judges and legislatures, while it may itself reflect customary experiences, is a means of overcoming this complexity and uncertainty.

Given these claims concerning the nature and central role of law in capitalist economies, legal institutionalism upholds that an understanding of legal rules is essential for economists and other social scientists. This is not to say that law is everything. Not all social rules are laws. As an evolved but also codified system facing a complex and changing economy, the law is necessarily incomplete and sometimes self-contradictory. There are important areas of social life that rely on frequent interpersonal action rather than the anonymous generalities of law. Nevertheless, the role of law is vital.

The very success of Western capitalism depends on the development of general national systems of legal enforceability. But these took a long time to establish. Even today, in much of the world, state systems of law enforcement are weak, expensive, corrupt or inaccessible. In the absence of adequate systems of law enforcement, people fall back on other means of establishing obligations and ensuring compliance. Commerce then works through clan or family ties, shared religion or ethnicity, bureaucratic co-option and corruption, or threats of violence to person or property. Simply because systems of spontaneous enforcement existed in history and persist today in certain contexts should not mislead us into believing that a fully-developed modern capitalist system rests on purely spontaneous or customary foundations.

Recognizing the centrality of law to the organization of economic and social life implies that law may vary from place to place with implications for the nature of contractual, property relations, or the organization of firms. Different legal systems can set the stage for different modes of social and economic ordering that seem to be remarkably path dependent (La Porta et al.,2008).

This paper has five further sections. It combines general points concerning the role of law, with a selective illustrative focus on some key capitalist institutions, namely property rights, contracts and the firm. Space constraints rule out discussion of money and financial institutions, for example. ${ }^{2}$ Section 1 considers the nature of law and argues that it is irreducible to custom or private ordering alone. Law involves a combination of customary input and legislative decree. Section 2 considers whether law is constitutive or epiphenomenal in modern society. Using Marx's base-superstructure metaphor, it is shown that law cannot be consigned to the superstructure. In addition, the state aspects of law should not be treated as secondary and epiphenomenal, as in some other accounts. Section 3 considers the nature of property and contract. It shows that property is often confused with possession, and analyses of contracts and exchange sometimes downplay the importance of legal rights and obligations. Section 4 on the firm shows how the introduction of the important feature of legal personality clears up some enduring confusions about the nature of the firm. Section 5 summarizes some key points, compares legal institutionalism with other institutional approaches in economics, and concludes the essay.

\section{The nature of law}

Some scholars suggest that custom is the key to understanding law. In turn, custom is seen as evolving without overall guidance and design. Writers in this tradition include David Hume, Edmund Burke, Friedrich C. von Savigny, Henry S. Maine, James C. Carter and Friedrich Hayek. Hayek's writings are among the most sophisticated. In his classic account of the foundations of law, Hayek (1973, p. 72) upheld that law "is older than legislation" and that law in some sense is "coeval with society." For Hayek, laws are simply the "rules which govern men's conduct" (p. 73).

The very concept of "customary law" is sometimes over-extended. Furthermore, contrary to the impression given by Hayek (1973) and others, common law is much more than custom, necessarily involving an institutionalized judiciary (Hasnas, 2005). Generally, customary mechanisms are insufficient to explain adherence to nationwide complex systems of law.

Where "customary law" is prevalent, it is often associated with politico-economic underdevelopment and failings or remoteness of the state legal system. When dealing with modern capitalism, law is a matter of state power; separate customary law dominates only in parts where the state cannot reach, such as in remote regions. The widening and development of capitalism has aided this encompassing process. Contracting parties have found it easier to submit to a single, powerful, legal authority. ${ }^{3}$

\footnotetext{
2 Money and financial institutions are discussed in Pistor (2013) and Hodgson (2015).

3 Private, custom-bound lex mercatoria or "law merchants" blossomed in Europe from the eleventh to the fourteenth centuries. But they declined and were eventually replaced by state enforcement (Baker 1979; Berman 1983, pp. 333-356; Milgrom, North and Weingast 1990). A major reason for their demise seems to be that they could not cope with the increasing scale and complexity of contracting.
} 
For other theorists, law necessarily involves the state. As the American jurist Joseph Bradley (1902, p. 230) put it:

It matters not how it came to be the law, whether it was prescribed by an autocrat or a legislative body, or arose from mere custom and usage, or the decrees of the courts - if the physical power of society, that is the State, is put forth for its vindication, it is law; if not, it is not law.

Emphasizing the state does not mean that custom is unimportant. The institutional economist Commons (1924) correctly argued that to be enforceable (at least in non-totalitarian societies) laws must be widely perceived as reasonable, appropriate and fair. Consequently, law must largely conform to established custom, even if it amounts to more than custom alone. Commons also emphasized that the collective power of the state also lay behind all property rights and transactions within capitalism. Custom is important to sustain law, but law is much more than an epiphenomenal expression of custom.

Consider accounts of the spontaneous emergence of law without the state (Greif, 1989, 1993, 1994, 2006; Benson, 1990; Ellickson, 1991; Greif et al., 1994; Landa, 1994; Hadfield and Weingast, 2012). In these models, some notion of law emerges through individual interactions, leading to the formation of conventional rules. Avner Greif and Janet Landa highlight reputational effects among ethnic groups. These accounts often refer to the emergence of legal rules in smaller-scale contexts, or with relatively weak law enforcement by the state.

Sened (1997) addresses standard explanations of the spontaneous evolution of property and contract that rely on reputation and other effects, involving smaller numbers of relatively well-informed traders. Sened points out that these conditions are generally absent in more complex and larger-scale societies, and rehabilitates a role for the state in the enforcement of property rights and contracts. He argues that private ordering based on reputational effects is insufficient to explain the enforcement of property rights.

Aviram (2004) argued convincingly that private ordering is generally insufficient to create an enforceable legal authority. A newly formed spontaneous order cannot alone enforce compliance, because mechanisms to secure this cooperation (such as the threat of exclusion) depend on its ability to confer benefits to its members, and a newborn order cannot yet confer such advantages, because it lacks the critical mass to do so. Hence what are described as "private legal systems" typically do not form spontaneously, but build on pre-existing institutions to secure initial compliance. Consequently, private ordering requires an institutional deus ex machina, such as the state or another strong prior institution.

Aviram's argument underlines the distinction between explanations of origin and explanations of persistence. Crucially, it is difficult for spontaneously emerging systems of law to gain the critical mass to become pervasive, notwithstanding the possibility that, once established, they may be sustainable. Many historical examples of allegedly spontaneous legal systems had nearby state systems of law, or involved numerous people who had experience of a state system.

Although privately ordered legal systems are possible in principle, and have existed historically, there are significant difficulties concerning their establishment, endurance and perceived moral legitimacy. Nobel Laureate Coase (1988, p. 10) wrote:

When the physical facilities are scattered and owned by a vast number of people with very different interests . . . the establishment and administration of a private legal system would be very difficult. Those operating in these markets have to depend, therefore, on the legal system of the State.

Knight (1992) argued that distributional differences and power asymmetries, rather than spontaneous outcomes of individual interactions, explain how laws are established. Especially when large numbers of people are involved, a state machine based on a monopoly of force is typically required to sustain property and other rights.

While law in complex societies depends on spontaneously-evolved custom, it also typically requires the powers and institutions of the state. Law in the modern sense did not exist in simpler and smaller societies. It generally requires a specialist judiciary within a stratified system of power. Furthermore, in modern complex societies, there is a legislature that has the capacity to act proactively and in response to socio-economic changes.

Legal institutionalism upholds that there is a qualitative difference between custom and law, and a line must be drawn between societies dominated principally by customary rules and those where a legal system with an institutionalized judiciary and legislature has also emerged (Hodgson 2009). If law were no more than custom, then all sorts of relatively minor rules, including grammatical rules of language and codes of politeness, would be laws. While all legal institutions are systems of rules, not all (customary) systems of rules are laws. By contrast, work by anthropologists and legal historians has shown that the evolution of law involves conflict resolution, institutions of law enforcement, and the transcendence of mere customary arrangements (Diamond, 1935; Seagle, 1941).

Law is an expression of state power. A statute in an effective legal system exerts normative force even when it is not immediately applied or followed. Even if a law is systematically violated or evaded, with the result that the role of the legal system as an effective mode of social ordering is called into question (see below our discussion of corruption), the existence of a formal law still has some institutional and hence economic significance.

Given this view of law as occupying a public space and as an expression of state capacity, legal institutions must also be regarded as historically specific phenomena, which, in the Western legal tradition, emerged in Babylonia roughly four thousand years ago, received their classic development and codification in Ancient Rome, and developed further in England and elsewhere in Europe from the twelfth century AD and thereafter (Berman, 1983).

In legal institutionalism, then, law is treated as more than custom: it is primarily constituted by the state. Once we consider the problems of enforcement in a complex legal system with many agents, and the motivational reasons why individuals might obey the law, then something like the state is required ultimately to ensure enforcement. Law emerges in hierarchical and complex societies with large numbers of individuals. The state must establish a monopoly of force, restrain 
vigilantism and minimize extra-legal violence. It uses law to accomplish these tasks, because the state's commitment to operate within predetermined legal constraints enhances its own legitimacy as a power wielder. Consequently, in practice, and with a few historical exceptions, generally involving small numbers and relatively low levels of complexity, law requires a state; conversely, the state is typically a necessary condition of law's existence.

Of course, there is nothing to prevent us defining law in a very broad sense that it includes custom. But then we would have to sub-categorize the law and label the important kind of law that depends upon an institutionalized judiciary or the state. This subcategory is what many legal scholars and ordinary people mean by "law." We adopt a narrower rather than an overly-capacious definition. In this view, law in the sense we are describing arose when customs were violated and some permanent and institutionalized higher adjudication was required. This type of law is indelibly associated with the historical rise of capitalism in recent centuries.

\section{Law: constitutive or epiphenominal?}

Various intellectual traditions have neglected the role of law in their analysis of modern socio-economic systems. Often law is regarded as a secondary expression of something else more fundamental. The influential view of Marx is criticized in this respect. In other prominent and more recent cases, solely the customary or "private ordering" aspects of law are regarded as fundamental. This widespread viewpoint shares with Marxism a relegation of the role of legislative and judicial legal institutions.

First consider the "base" and "superstructure" metaphor that is central to Marxism. In 1859, Marx (1971, p. 20) argued that this base consisted of the "totality of ... relations of production" which "constitutes the economic structure of society, the real foundation, on which arises a legal and political superstructure." Similarly, Marx (1971, p. 21) saw "property relations" as "merely" an expression "in legal terms" of these "relations of production" in society. He argued that "it is always necessary to distinguish between the material transformation of the economic conditions of production" and "the legal, political, religious, artistic or philosophic - in short, ideological forms." Hence Marx saw law as relatively superficial and of lower ontological status than the "material" and "economic conditions of production." Similarly, in the first volume of Capital, Marx (1976, p. 178) regarded the "juridical relation, whose form is the contract" as something that "mirrors the economic relation" where "this juridical relation ... is itself determined by the economic relation." This again suggests that legal forms are surface phenomena.

Whatever the "economic structure" might mean, for Marx its fundamentals do not include legal relations. The law was seen as an expression or reflection of "economic relations" or "relations of production." What Marx ruled out is the possibility that laws may be a necessary and essential part of these "economic relations" or "relations of production."

For Marxists, class and class struggle are central. In the first sentence of the opening chapter of the Communist Manifesto of 1848, Marx and Engels (Marx, 1973, p. 67) declared: "The history of all hitherto existing society is the history of class struggles." But after forty years had elapsed, Engels felt obliged to define the two main classes of modern capitalism, the bourgeoisie and the proletariat. To the 1888 English edition he added a note:

By bourgeoisie is meant the class of modern capitalists, owners of the means of social production and employers of wage labour. By proletariat, the class of modern wage labourers who, having no means of production of their own, are reduced to selling their labour power in order to live (Marx, 1973, p. 67 n.).

When it came to defining these crucial classes, Engels was obliged to refer to concepts such as ownership, employment of waged laborers, and the selling of labor power. None of these terns can be defined adequately without reference to law and legal ideas. Ownership - in the fullest sense - implies legal rights, enforced by recognized contract and the legal powers of the state. ${ }^{4}$ The employment contract is a specific legal form, differing from a contract for sales or services. Selling implies the legal transfer of property rights, on a temporary or permanent basis. The selling of labor power involves the legal transfer of limited rights of authority over the laborer and the use of her capacities toward contracted purposes. Law appears in the definitions of social classes which are regarded as fundamental. So law too must be at the foundation.

Marx and Engels were unconvincing in their consignment of law to the more superficial superstructure. Law is constitutive of social relations, and is necessary for the definition of modern social classes. Law is not an epiphenomenon. In modern societies it is a central mechanism of social power.

Modern societies proclaim equality before the law. But differential access to education, lawmakers and law enforcement creates an uneven playing field. Powerful actors can influence the making or implementation of law. Marxists are right to highlight the role of the rich and powerful. But law itself is power and not merely its instrument. The rule of law puts restraints on power by circumscribing the actions of the executive and subjecting them to judicial oversight, as well as providing diverse opportunities for its advancement as regulators can use their secondary law-making powers to advance their own agenda. Law can shift the balance of power as different actors discover how best to use the law to advance their interests.

Apart from Marxism, and throughout the social sciences, law is downgraded in various ways. For example, as noted above, Hayek saw custom as the essence of law, thus regulating the legal institutions of the state to a secondary role. Similarly, new institutional economists such as Williamson (1975; 1985a, 1985b) have emphasized "private ordering" over state

\footnotetext{
${ }^{4}$ Below it is shown that both Marxist and mainstream conceptions of property or ownership are defective in terms of their understandings of rights.
} 
legal institutions, including courts and legislatures. Again the law is conceptually downgraded. Institutions of law that are entwined with the state are regarded as epiphenomenal to customary and private ordering, rather than regarding the state and customary aspects of law as mutually constitutive. Consequently, when Hayek, Williamson and others overemphasize custom and private ordering, to the neglect of the essential role of the state, they end up treating the state aspects of law as secondary and epiphenomenal. In this respect their position is similar to that of Marx.

Further similarities between Marxism and other schools of thought that downgrade law are explored below. ${ }^{5}$ In particular, there are uncanny similarities in their mutual treatments of the concept of property.

\section{Law, property rights and exchange}

The aim of this section is to show that the commonplace removal of key legal considerations, such as institutionally legitimated rights, from key economic concepts, such as property, contract and exchange, has serious negative consequences in terms of understanding their nature and function in modern capitalism.

Legal institutionalism insists that property is more than possession. Yet many social scientists fail to make this distinction. Possession refers to the control of a good or resource. It is more about the ability to make effective use than any established right to do so. Possession is principally a relation of control by a person over a thing. Possession does not amount to legal ownership. As R Pipes (1999, p. 15) put it: "Possession refers to the physical control of assets, material or incorporeal, without formal title to them: it is ownership de facto not de jure." Although some laws recognize possession as separate right in rem and property often implies but does not necessitate possession, the two are not the same:: "Property refers to the right of the owner or owners, formally acknowledged by public authority, both to exploit assets to the exclusion of everyone else and to dispose of them by sale or otherwise." The crucial difference here involves the granting of formal rights by public authority. Hence property in the truest sense of the word has another prerequisite - the political authority of the state. "Before the state there is only possession" (Pipes, 1999, p. 117).

Property is a relationship between persons involving rights and duties, with regard to things (Commons, 1924; Hallowell, 1943). The essence of the right of ownership of a resource is its acknowledgement of that right by others who may have never met the owner and have not entered into any contractual relation with her, through mechanisms of legal accreditation and legitimation. As Penner (1997, p. 3) puts it: "Viewed in this way, property is a creature of its environment, the legal system."

Honoré (1961, p. 115) wrote: "To have worked out the notion of 'having a right to' as distinct from merely 'having' ... was a major intellectual achievement. Without it society would have been impossible." As Honoré (1961, p. 134) argued: "It is not enough for a legal system to recognize the possibility of people owning things. There must be rules laying down how ownership is acquired and lost and how claims to a thing are to rank inter se." The legal title to an object of property refers to the conditions that must be fulfilled in order that a person may acquire a claim to a thing.

Different types of property right include the right to use a tangible or intangible asset (usus), the right to appropriate the returns from the asset (usus fructus), the right to change a good in substance or location (abusus), the right to the capital derived from the use of the good as collateral, the right to sell a good (alienation), and several other rights or limitations (Hohfeld, 1919; Honoré, 1961, p. 113; Pejovic, 1990, p. 28). The distinction between different types of property right is crucial for the workings of any modern economic system. For example, hiring or leasing something may confer the right of use for a while, but not necessarily other rights.

Crucially for the functioning of the modern capitalist system, and unlike objects of mere possession, durable property can be used by its owner as collateral and can involve legal encumbrances (Arner et al., 2007; Steiger, 2008; Heinsohn and Steiger, 2013). The registration of property and its use as collateral for debt is a crucial institutional mechanism for economic development (De Soto, 2000; Arruñada, 2012).

Yet many social scientists treat property principally as a relation between an individual and a good, thus downplaying the fact that the institution of property also involves social relations between individuals, and between individuals and the state. The primary focus is on the individuals, goods, and individual incentives. The institutions that sustain and legitimate property are given inadequate attention.

Classic accounts by economists Demsetz (1967) and Posner (1980) discuss the origin of "laws" of "property" in primitive societies. These are not so much wrong as mislabeled. Both writers conflated law with custom. Demsetz's discussion of the origin of "property rights" is about the origins and motivations for customary rather than legal rights. Posner addressed primitive "laws" concerning property, contract and marriage. His main claim was that various forms of these institutions were "rational" in the context of prevailing information costs and other factors. But his arguments concern custom, rather than law in the more appropriate sense. And instead of property he describes possession. Much of Posner's argument concerning property rests on elaborate "insurance" arrangements between parties that Knight (1992, p. 114) persuasively argues are unfeasible, principally because problems of uncertainty and complexity are downplayed.

Alchian (1977, p. 238) defined the "property rights" of a person in the universal terms of "the probability that his decision about demarcated uses of the resource will determine the use." The upshot of this definition is that if a thief

\footnotetext{
5 Some libertarian-individualist writers have adopted formulations uncannily similar to Marxism. For example, a book edited by Pejovich (1997) is titled The Economic Foundations of Property Rights. But the meaning of these "economic foundations," and how they are constituted before property rights are built upon them, is unexplained. Arguably they are inseparable (Deakin 2006).
} 
manages to keep stolen goods then he acquires a substantial property right in them, even if, on the contrary, legal or moral conclusions would suggest that they remain the rightful property of their original owner. Alchian's definition of property neglects the essential concept of rightful ownership. It denotes possession rather than property. Accordingly, Grossman and Hart (1986, p. 694 n.) claim that ownership is "substantially the same" as possession.

Despite its centrality, the concept of property is strangely underdeveloped in mainstream economics. There is, it is true, a sizeable sub-discipline known as "the economics of property rights" (Furubotn and Pejovic, 1972, 1974). But if we look at this closely then it is clear that the discourse is primarily about individual incentives rather than about property. To the property rights economists, the "structure of property rights" refers primarily to a set of incentives and disincentives for specific individual actions - a Benthamite calculus of pleasure and pain - but not essentially to the institution of property itself.

Again there is a remarkable resemblance with Marx's view. His numerous discussions of "property" had little to say about legal rights, and he conflated property with possession. Hence Marx (1975, p. 351) in 1844 addressed "private property" and argued that "an object is only ours when we have it - ... when we directly possess, eat, drink, wear, inhabit it, etc., - in short, when we use it." With both Marx and "the economics of property rights", effective power over something, i.e. might, makes a de facto right. Legal and moral aspects of property are overshadowed.

The near-universal neglect of legally legitimated rights in the treatment of 'property' has major deleterious implications. It weakens our understanding of the role of the state in sustaining a system of property and it generally relegates the role of institutions, instead to focus on physical relations between people and objects. The discourse of rights is vital to understand how these institutions work and how people are motivated in their dealings with property. As a particular illustration, addressing environment resource management, Hoffman (2013, p. 39) argued "that the distinction between possession and property is of particular importance for comprehending the meaning of institutional shifts from one resource management regime to another."

Lueck and Miceli (2007, p. 187) concluded that much of literature in economics on property rights "remains ignorant of property law." As Arruñada (2012, p. 24) pointed out, much economic analysis treats property as a relatively unproblematic distribution of entitlements and moves analytical attention toward contracting difficulties and transaction costs. Property rights are too important to be left to economists. While the distinction between possession and property is ignored by Marxists and mainstream economists, it is of supreme analytical and practical significance.

Stating that property rights are critical for modern capitalist systems is not to say that there is only one way to establish them. Neither does it imply that private property rights are causally related to growth in any direct fashion. Whether or not this is the case is ultimately an empirical question and evidence suggests that it varies over time and depends hugely on sample selection. The point of this essay is to stress the fact that property is a legal institution and that law therefore must be at the center of a meaningful analysis of property rights as well as the exchange of assets.

Terms such as exchange or contract suffer a similar evacuation of meaning, not only in much of economics but also in sociology. As with "property" the meaning of "exchange" has been stretched to the point that it has become eroded of meaning and historical specificity.

In sociology the "exchange theory" of Homans (1961) and Blau (1964) proposes that a wide range of activities - including gift-giving and interpersonal communications - are "exchanges." Similarly the sociologist Coleman (1990, p. 37) saw exchange as simply a "pairwise exchange of resources" without the necessity of a reciprocal exchange of property rights. In modern social science, concepts such as "exchange," "contract" and 'transaction' are used habitually and without explanatory ado, as if their meaning is always crystal clear. Yet this is far from the case; the meanings of these concepts cannot be taken for granted.

This ahistorical concept of exchange in sociology obscures its specific, contractual form in a market or capitalist society. As Rau (1835), MacLeod (1878) and Commons (1924) rightly insisted, an exchange of commodities involves the contractual interchange of property rights, along with the transferred goods or money. Unless a transfer of property rights is involved, it is not properly described as an exchange. Property rights, in turn, are backed up by custom and legal sanctions. Exchange has to be understood and analyzed in terms of the key social institutions that are required to sustain it.

More broadly, a legal contract is an agreement entered into voluntarily by two or more parties with the shared intention of creating legal obligations. It may be made in writing, verbally, or by other signaled assent. Such a contract could involve the delivery of services or the exchange of goods. Of course, not all agreements between adults are legal contracts. Many are acts of reciprocity between friends and family without any intention of recourse to law if they are breached. This is recognized by the law of contract itself. But in the wider world of commerce, potential recourse to law to enforce contracts is vital. An effective legal system involving contract law is important to extend the sphere of exchange throughout society and reap its benefits.

In business, as Macaulay (1963) famously observed, most deals are enforced without any appeal to the courts, and many even without written contracts. But this does not mean that legal institutions have no place in everyday commerce. As Greif, Milgrom and Weingast (1994, p. 746) put it, "the effectiveness of institutions for punishing contract violations is sometimes best judged like that of peacetime armies: by how little they must be used." Where the rule of law prevails, the mere possibility of access to the courts is sufficient for the legal system to bear down upon contractual agreements; hence many apparently self-enforcing agreements are actually contracts made "in the shadow of the law" (Mnookin and Kornhauser, 1979). 
The reinstatement of the full legal meanings of property, contract and exchange is essential not simply to understand the nature of capitalism, but to give sound and well-grounded policy advice concerning the key institutions of capitalist development. Accounts that rely simply on the spontaneous development of the necessary legal infrastructure for a capitalist economy are ill-grounded and inappropriate for large and complex societies. Relatedly, accounts that omit the key feature of legally-legitimated rights focus on physical, agent-object relations and activities, to the neglect of the legal and other social institutions that are necessary for capitalist prosperity.

\section{Law and the firm}

In this section, we extend the above argument to firms by suggesting that they too have to be treated as creatures of the law, where law itself is irreducible to custom or private ordering. Recognition of legal form solves some enduring problems in the theory of the firm. We use the term firm to apply to individuals or organizations with the legally recognized capacity to produce goods or services for sale. A corporation is a kind of firm; it has a structure as designated under corporate law. All corporations are firms, but not all firms are corporations. ${ }^{6}$

Coase (1937) in his classic article treated the firm and the market as two alternative ways of organizing productive activity. The firm was defined in terms of its "supersession of the price mechanism" (p. 389). For Coase (p. 391), owners of factors of production do "not have to make a series of contracts" with other factor owners in the production process: "For this series of contracts is substituted one." Each factor owner makes a contract with the "entrepreneur," which was defined as "the person or persons who ... take the place of the price mechanism in the direction of resources" (p. 388 n.).

Note that Coase's account depends on several legal concepts, including owner, sale and contract. It was not that he was concentrating purely on "economic" issues, whatever that might mean. It can be objected that Coase's concept of "the market" is overly spacious and one must consider relational exchange as well as markets in the sense of ongoing organized exchange. But the biggest problem in his classic article is his treatment of the firm itself. Unless this problem is fixed, his firm-market dichotomy disintegrates.

Coase (1937) regarded the "entrepreneur" as one or more people. First assume it is one person. This person then enters into legal contracts with employees and suppliers of materials, and production takes place. Clearly this firm is a legal entity in the sense of being structured by relations of property and contract law, before we even consider whether it has distinct legal capacity as a "corporation." Coase may have assumed, but did not clearly state in this article, that the entrepreneur owns the product, and has the right to the revenue from the goods or services that are produced. Instead of entrepreneurial ownership rights and potential liabilities, he concentrates on the administrative function of the entrepreneur, and on details of the employment contract (p. 391). However, there is nothing natural about the idea that the residual profit from production vests in the entrepreneur; this results from the legal allocation of property rights in the surplus from production.

Because Coase concentrated on the input-contracting and administrative functions of the entrepreneur, he overlooked another important issue. Who is to be sued if the output of the firm proves defective or dangerous? Is it the entrepreneur, or the individual worker responsible for the defect? For there to be a firm, as opposed to a series of bilateral contracts, there must be some entity, which is the locus of legal liability. But because Coase was insufficiently clear on the matters of the rights and duties of ownership of the product, he missed this point entirely.

These problems are compounded if the "entrepreneur" is more than one person. For instance, what are the ties or incentives that keep the entrepreneurs together as a team? Coase (1937) was silent on this point too, but there must be some legally enforceable arrangement that keeps them together, and allows them as a body to make the contracts with the owners of factors of production. Employees and suppliers would not make separate contracts with each of the entrepreneurs as individuals, so with whom are they are contracting? Likewise, if the firm sells a defective product, then which entrepreneur gets sued? Or are they sued as a body, in which case how would the liability be shared between them?

If the entrepreneurs were partners then they would often be bound together by a legal partnership agreement or articles of partnership. This agreement would specify management responsibilities, shares of profits or losses, and mechanisms to resolve disputes between partners. Unlike the members of a corporation, partners are jointly and severally liable for partnership debts. The glue holding the firm together, and making it a singular unit, is the agreement of joint responsibility between the partners. Contrary to Coase, the partnership firm is not constituted by entrepreneurial administration of a production process, but by the legal presumption that those joining forces to pursue entrepreneurial activities also share in the responsibilities of these activities.

If Coase's entrepreneurs were in a corporation then they would typically be its shareholders or managers. Legal incorporation means that the state recognizes the firm as a singular legal person with rights and duties. The corporation does not simply consist of its entrepreneurs. Neither the entrepreneurs nor the shareholders own the corporation. The corporation

\footnotetext{
6 Robé (2011, p. 3) argued that firms and corporations are "totally different concepts: a corporation is a legal instrument, with a separate legal personality, which is used to legally structure the firm; a firm is an organized economic activity, corporations being used to legally structure most firms of some significance." We would agree to the extent that "corporation" is a legal term of art whereas "firm" mostly is not. Also, firms as productive entities (a necessarily broader notion than Robé's reference to an "activity") may not have legal personality as such, and embrace many economic relationships in addition to those described by corporate law. However, qualifying Robé's point, we suggest that the term "corporation" can be used to describe productive entities of a certain kind, above all those which are legally structured in a particular manner and hence take on distinct economic characteristics (Deakin, 2012).
} 
itself is an owning agent; that is to say, ownership of the assets of the firm are vested in the legal person, the corporation. Nor is the corporation a res or thing which the shareholders can be said to own (Deakin, 2012). Shareholders own shares in the corporation, in principle not the corporation itself (Blair and Stout, 1999; Ireland, 1999; Robé 2011). Although there are plenty of corporations with only a single shareholder, including corporations owned by other corporations, we still cannot equate the corporate form with the single shareholder; both in law and in practice, they are distinct. The corporation hires the workers, buys machines and raw materials and sells the output. The corporation is sued if it sells defective products and sues if it suffered damages from breach of contract and the like. The glue binding the corporation together is the power of corporate law, the adoption of its principles by the shareholders, and the agreement between them. Contrary to Coase, the corporation is not constituted by entrepreneurial administration of a production process, but by establishment of the singular legal person under which the entrepreneurs operate.

Eventually this defect caused Coase to abandon a strict firm-market dichotomy. Coase (1988, p. 27) declared a revised position: "I have come across numerous examples of markets found within firms, but one which amused me was the discovery of a kind of market operating in the heart of a nationalized industry in England, the electricity supply industry." Coase then quoted from a 1961 lecture given by an official of the Central Electricity Generating Board: "the National Control Room becomes in effect an auction room, with a National Control Engineer asking the Regional Centres to quote the price at which they could supply a certain number of kilowatts at specified periods during the following day. ... Wherever possible he accepts the lowest bid." But once we apply clear legal criteria concerning contracts and ownership, Coase's argument disintegrates. The UK Central Electricity Generating Board (CEGB) was itself a singular legal person. The regional centers were not legally separate firms but internal divisions of the CEGB. A complainant would sue the CEGB, not the regional centers, just as the CEGB would sue any supplier to a regional center that did not fulfill a contract. The regional centers neither owned nor sold electricity to the CEGB. Any semblance of contract between the regional centers and the CEGB would not have been recognized in law as such. It was not an exchange of property rights because ownership of the electricity remained in the hands of the CEGB throughout. Instead, the bidding and "selling" of electricity was an internal management mechanism to reduce costs and encourage increases in productivity.

There are often internal negotiations and transfers of resources between divisions of modern firms. These divisions may have their own accounts and profit targets. Most firms use price indicators for internal accounting. But are there "internal markets" within firms? Again a key test is whether or not these divisions have separate legal status, and are recognized as legal persons. Internal transfers within the firm do not involve the exchange of legal property rights. The objects of "exchange" remain the property of the firm. These "exchanges" are not legally enforceable contracts of trade: they are internal transfers. If a division of the firm is delegated the power to enter into contracts with outside bodies, then the firm as a whole is legally the party to the contract. The division acts in the name of the corporation, and the corporation as a whole is legally responsible for its liabilities under the agreed contract. Because the firm is a singular legal entity, it cannot make contracts within itself, just as our legs cannot make a legal contract with our brain to walk or run when instructed.

Like Coase, Oliver Williamson chose to concentrate on the internal organization of the corporation and to downplay its legal peculiarities and its legal singularity. Williamson (1985a, p. 318) noted that "the centrality of management ... distinguishes it from all other constituencies." Williamson (1985b, p. 199) further explained: "whereas each constituent part of the enterprise strikes a bilateral deal with the firm ... management has knowledge of and is implicated in all of the contracts." But this formulation encountered the very same problems that we have observed with Coase. What legal arrangement binds management, the officers and directors of a corporation, together? Being "implicated in all of the contracts" is not the same as making them jointly or in the name of a single entity.

Due to his preoccupation with private ordering, Williamson downplayed the firm as a legal entity. Williamson (1985b, p. 184) wrote: "Since the efficacy of court ordering is problematic, contract execution falls heavily on the institutions of private ordering ... This is the world with which transaction cost economics is concerned." But he did not demonstrate that the efficacy of private ordering is less problematic. For unconvincing reasons, Williamson's conception of transaction cost economics excludes the role of publicly articulated legal rules. This is a serious impairment for the research program, and it is fatal for attempts to establish a clear identity for corporations and other business organizations.

For Williamson what mattered was the nature of these contracts and the governance mechanisms involved in their monitoring and enforcement. The firm was treated as a group of individuals, such as partners or shareholders, who make contracts with each other and jointly with others. There is nothing here to make the firm a unitary entity or establish clearly how different stakeholders relate to one another. Partners may be each other's agents, but directors and officers are agents of the corporation, not of the shareholders. The distinction between the firm and the market quickly faded. Hence Williamson (1985a, p. 83) was "persuaded that transactions in the middle range are much more common," while hierarchies (or firms) become "a continuation of market relations by other means" (Williamson, 1991, p. 271). He became an advocate of the firm-market continuum. Williamson (2007, p. 376) wrote:

"What defines a firm at the end of the continuum? I take the defining characteristics of governance structures to be incentive intensity, administrative control, and the contract law regime. Firms combine relatively low powered incentives with a lot of control instruments and use hierarchy rather than courts to settle disputes. Markets are polar opposites, and hybrids are located in between."

As with Coase (1937), the focus was on the contractual or administrative organization of production and its internal incentives. Likewise absent here is any explicit notion of the person or contracting entity that owns the means and fruits of 
that production, or can be sued if its outputs are defective. Although the research program has moved from a dichotomy to a continuum, these sizeable omissions have been thematic for Coase-Williamson-type transaction cost economics from the beginning.

It became respectable for other economists and sociologists to argue that the boundaries of the firm were fuzzy and indistinct. Ideas emerged of "internal markets" within firms (Doeringer and Piore, 1971), of the "quasifirm" (Eccles 1981), of "strange forms" (Ménard, 1995, 1996), and the abandonment of any attempt to define the firm (Cheung, 1983). The arguments went like this: the kind of contracting we observe is typical of neither a market nor a firm, so it must be some kind of "hybrid" of the two. This ignored the possibility of (non-market) relational exchange along the lines of Richardson (1972), Goldberg (1980) and Dore (1983). Most of these relations are, however, rooted in law. Contracts may be open-ended and may commit the parties to cooperate rather than to detailed obligations. All of these arrangements have different ramifications in law. They do not exist outside the law, but are framed by it.

With Alchian and Demsetz (1972) the firm became simply the individual residual claimant who monitors the team. It is she alone who reaps the profits, and may sue suppliers, or be sued by customers. The firm can only be a self-employed contractor, and other forms, such as the partnership or corporation, are excluded or ignored. If an attempt were made to include organizations of multiple human individuals as firms, then the alleged monitoring problem would re-emerge, and one of these individuals - according to their logic - would have to become the residual claimant. The multi-individual firm would then revert back into a single-individual entity. Despite the insights in this important paper, it cannot deal adequately with modern corporate forms.

Jensen and Meckling (1976) identified a key defect in the approach of Coase and Williamson - its failure to take into account contractual relations other than with employees and suppliers. Jensen and Meckling (1976, p. 310) wrote: "Contractual relations are the essence of the firm, not only with employees but with suppliers, customers, creditors, and so on." Contracts with customers are also taken into account. Jensen and Meckling (1976, p. 311 n.) also acknowledged the role of law in a footnote:

"Statutory laws sets [sic] bounds on the kind of contracts into which individuals and organizations may enter without risking criminal prosecution. The police powers of the state are available and used to enforce performance of contracts or to enforce the collection of damages for non-performance."

This is a rare acknowledgement of the significance of the legal aspect of the firm. But for them the firm is simply a "legal fiction which serves as a nexus for contractual relationships" (Jensen and Meckling, 1976, p. 311). "Viewing the firm as the nexus of a set of contracting relationships among individuals," Jensen and Meckling (1976, p. 311) warned that "the personalization of the firm ... is seriously misleading. The firm is not an individual."

But it needs to be emphasized that legal fictions are not false (Fuller 1967). They are devices used in legal reasoning to transfer principles that have been established in one context to another. In the case of the corporation, the legal fiction involves a transfer of rights and liabilities concerning ownership and contracting from individuals to registered corporate organizations. This does not mean that the law grants corporations all the rights that it grants to individuals. The rights it does grant are subject to change, limitation and dispute. The rights and liabilities that are important here concern the rights to own assets, enter into contracts, to sue, and be sued. But in establishing a legal person, the law imposes conditions on how these powers can be exercised. Modern corporate law allows corporations to be freely formed, but requires that its governance structures are transparent and the rights of shareholders and directors or officers are clearly identified. This would not be the case (or even meaningful) if the law treated the corporation exactly as an individual.

Jensen and Meckling (1976) failed to acknowledge these nuances. They view the firm as "a set of contracting relationships among individuals" (p. 311) but do not show how this "nexus" itself forms a contract with suppliers or customers when it is no longer deemed to be a singular legal entity. They do not consider how the problem of how to deal with the death, bankruptcy, or insanity of one of the individuals that makes up the nexus. In short, they evade the issue of how the firm survives the legally-operational lives of the individuals in the nexus. They also failed to recognize that the corporation faces critical life and death events that differ from simple contractual relations - including the merger, acquisition, or liquidation of the entity.

The "new property rights theory" of Grossman and Hart 1986, Hart 1989, 1995, Hart and Moore 1990 and Moore 1992 built on several preceding theories but were critical of their limitations.

Grossman and Hart (1986, pp. 692-693) "define the firm as being composed of the assets (e.g., machines, inventories) that it owns. ... We define a firm to consist of those assets that it owns or over which it has control." Or, more crudely, the firm is viewed "as a collection of physical assets" (Hart and Moore, 1990, p. 1121). But a pile of physical assets is insufficient to constitute a firm. Ironically it misses out the property rights over these assets that are supposedly at the core of their theory.

Grossman and Hart (1986, p. 693) saw the problem in previous theories as the lack "a sufficiently clear definition of integration." In their theory "the firm" owns these assets and holds rights of control over them as well as the rights to the residual income of the enterprise. Hart (1995, p. 57) argued: "A firm's nonhuman assets ... simply represent the glue that keeps the firm together." But this formulation is inadequate and clumsy. A collection of assets cannot "simply represent the glue that keeps the firm together." Even in their own terms it is ownership or control of these collections of assets that provides the firm with power over employees and suppliers. These powers are backed by law. Grossman, Hart and Moore paid even less attention to the legal nature of the firm than some of the competing theo- 
ries. Hart (2011, p. 102) asked: "is a firm circumscribed by its legal status or by its economic activities?" This is a false and misleading dichotomy. The "economic" activities of the firm become possible because the firm has a legal status, and has powers enshrined in law. As Deakin $(2006,2012)$ explained, legally recognized capacities define conditions of access to the market; the capacity to own assets and enter contractual relations. As Iacobucci and Triantis (2007, p. 518) put it:

"Legal persons may vindicate their ownership rights in court, and they may be defendants against whose property creditors may enforce their claims. Accordingly, only a legal person has the capacity to contract - that is, to make a legally enforceable pledge of its assets to the performance of its promise."

Collections of assets without a legal person as their owner are no more a firm than a collection of bones, flesh, and blood is a human being. Once the legal and ownership aspect of the problem is fully acknowledged, then we face the question of how the firm establishes itself as a unitary organization, despite the frequent involvement of multiple directors or shareholders. As Holmström (1999, p. 100) put it: “property rights theory, as articulated in Hart and Moore (1990) and other representative pieces, says very little about the firm. The problem is that there are really no firms in these models, just representative entrepreneurs."

These puzzles concerning the nature and identity of the firm are solved once we recognize it as a legal entity. ${ }^{7}$ The glue that holds the firm together consists of the legal provisions that bind the parties into one legal entity, and in turn draw on appropriate legislation. An entrepreneur or an association of resource owners become a firm upon the acquisition of a legally-recognized separate legal personality; its ownership of assets is secondary. In the case of the corporation, the glue can outlast the lifetimes of the individual members involved. Their individuals and assets may change many times over. The firm is distinct from its human constituents. A coalition of owners may create a firm. And firms typically own non-human assets. But the firm is not the same thing as a coalition or a collection of assets.

There is no good reason for economists to relinquish a legally-grounded definition of the firm or corporation. All major theories of the firm depend on legal concepts - particularly ownership - despite the neglect of the firm itself as a legal entity. Legal specifications and frameworks are vital for the firm to operate. Legal relations are an unavoidable part of the definition.

This argument is not undermined, but strengthened, by the real growth of other economically significant entities such as business units, conglomerates, strategic alliances, supplier networks, relational contracting and so on. Each of these entities makes use of legal forms, including contracts, property rights, or different forms of business organizations and combines them in different ways. In fact, the growth of a diversity of business and industrial structures makes it imperative to develop clear, distinct definitions of the different entities involved and to understand their legal structure. A muddled or mutable reality is no excuse for muddled definitions. Especially to understand a complex reality we need clear concepts and careful definitions to guide us.

Legal personality has clear advantages in regard to uncertainties and complexities surrounding any longstanding contract, and the required flexibilities that are needed to face an unpredictable future. Rather than contracting for everything in advance, entrepreneurs rely on evolved commercial law and the choices of legal template on offer. As Robé (2011, p. 17) argued:

"One of the key advantages of creating a juridical person owning or controlling the assets used in the business is precisely that it avoids having to agree in advance on detailed contracts among the shareholders to specify who will do what in what circumstances and get what in return. All the rights, including the residual control rights in connection with the various assets contributed to the business, are now owned by the "artificial" juridical person, not by any of the contracting parties. The so-called "legal fiction" of the corporation, far from being negligible in economic analysis, is actually central to it."

Nowhere is this better reflected than in the legal standards that govern the conduct of directors and officers of the corporation. Their extensive powers to manage the corporation could easily give rise to abuse were it not for the broadly defined fiduciary duties the law imposes on them. Hence a major reason for the adoption of the corporate form is to help cope with future uncertainty. There are further reasons for the economic effectiveness of the corporate form. Blair (1999, 2003) has argued that legal entity status protects corporate assets by "locking-in capital," so that it can neither be retrieved by the shareholders nor taken away by lawsuits from creditors. Similarly, Hansmann, Kraakman and Squire (2006) wrote of the "entity shielding" function of the corporation, which protects corporate assets from the personal creditors of its shareholders, and conversely the shareholders' creditors from those of the corporation. These reasons explain why ownership rights to assets are vested in the corporation itself, and why contracts are made with corporations rather than with their shareholders.

From the perspective of legal institutionalism, the firm (including the corporation) has at least two fundamental features: (1) it is set up to produce goods of services for sale, and (2) in owning assets, contracting inputs and selling outputs it acts as a legal person. As a legal person, the firm has legal ownership of the goods as property up to the point that they

\footnotetext{
7 The importance of the legal nature of the firm is recognized by Masten (1991), Phillips (1994), Blair (1999, 2003), Iwai (1999), Hodgson (2002), Hansmann, Kraakman and Squire (2006), Gindis (2007, 2009), Iacobucci and Triantis (2007), Spulber (2009), Robé (2011), and Deakin (2012).
} 
are exchanged with the customer, the legal right to obtain contracted remuneration for the produced services, and the potential liability to be sued for non-fulfillment of contracts with suppliers or customers, or for tort if defective products cause harm. We suggest that if a productive entity is not legally structured in this way, it is not, in economic or other terms, a "firm."

\section{Further applications and conclusions}

The case studies of property, exchange and the firm have shown the limitations of a purely spontaneous conception of law. Among the reasons why a legal system has to rest in part on the state - that is, on public ordering - is the high degree of complexity and uncertainty in large, developed economies. One of the key features of legal institutionalism is its recognition of this complexity and uncertainty.

It has been argued above is that the legal system is part of the state, and the state is part of its make-up. Consequently, the state is an essential rather than an accidental property of law. But at the same time, custom is also a vital basis for law, and is also non-accidental. Law embodies both private (spontaneous) and state (designed) elements, among its nonaccidental properties. These dissimilar elements are part of the "essence" of law. Accordingly, Pistor (2013) uses the term "essential hybridity" to describe this combination.

Legal institutionalism shares with other institutional approaches an emphasis on the importance of social rules. Indeed, rules are the stuff of social life and institutions are essentially systems of shared social rules. As Dopfer, Foster and Potts (2004, p. 263) put it: "an economic system is a population of rules, a structure of rules, and a process of rules." ${ }^{8}$ Legal institutionalism adds to this the further claim that many of the more important and powerful rules are legal in character, and they are backed by the power and authority of the state.

One immediate consequence of this vision is the literal impossibility of complete de-regulation, or of an unregulated economy or market. Rules are everywhere, and are essential to social and economic life. All that can be attained is to change some rules, or to remove some to allow others to do more work. Rather than universal de-regulation, legal institutionalism addresses the difficult research question of what kind of rules are appropriate for each particular circumstance. Given the complexities and uncertainties involved, such an approach must be cautious and experimental, and cannot proceed on the basis of complete prior design.

Legal institutionalism also illuminates the phenomenon of corruption. Corruption has its apologists, such as those who claim that it oils the wheels of commerce, or that if it is done by mutual consent it must be Pareto efficient (Huntington, 1968). Especially in the context of bureaucracy and underdevelopment, corruption may seem to be the only way to get things done. Once again, this view assumes that markets and business naturally operate outside law and state institutions; law and regulation give rise to corruption because they increase the costs of commerce. From the perspective of legal institutionalism, however, corruption appears as the negative image of legal ordering. It is sometimes defined as the use of the price mechanism where it is outlawed - as in dealings with the bureaucracy (Rose-Ackerman, 1999). What is outlawed is of course a question of legal design. Corruption can thus serve as a barometer for the reach of legal ordering in a society or its rejection. The social costs of corruption may be huge (Hodgson and Jiang, 2007). They include the corrosion of the legal system, in favor of elite interests and nepotism. Evidence shows that corruption stultifies effective economic competition, undermines investment, inhibits the rule of law, undermines effective state administration, and promotes political instability. Several empirical studies indicate that corruption has negative effects on economic performance. ${ }^{9}$ Given the importance of effective law and functioning legal systems in economic development, reduction in the levels of corruption is an important priority. This, however, cannot be done through law alone, or by removing law where it is critical for constituting firms, markets, and exchange. Instead, the phenomenon of corruption evidences that the success of legal solutions depends on their legitimacy in the eyes of law's addressees.

What has legal institutionalism in common with the original institutionalism in economics and the new institutional economics, and how does it differ from them? Answering this question is tricky because both institutionalisms have contained a diverse range of thinkers, with some overlap between the two traditions. In recognizing the historical specificity of property, contract, exchange and firms, legal institutionalism shares an important insight from the original institutionalism. Furthermore, the original institutionalist Commons placed particular emphasis on the role of law, which he regarded as a historically specific combination of both judicial decree and custom. Other leading original institutionalists recognized the economic role of law, but gave it less emphasis. The contribution of Thorstein Veblen, for example, was more to do with the nature and evolution of institutions (Camic and Hodgson 2011). But both Veblen and Commons emphasized the importance of intangible as well as tangible assets, thereby opening the door to a less physicalist and object-oriented conception of the economy.

New institutional economists have made major contributions to the development of the interface between law and economics, but sometimes treat law as a matter of custom or private ordering alone: this is particularly the case with Williamson. But on the other hand, North, Wallis and Weingast (2009) have stressed the role of law in general and of legal incorporation of business firms in particular, in underpinning economic development and growth.

\footnotetext{
${ }^{8}$ See for example North (1990), Crawford and Ostrom (1995), Searle (1995, 2005), Hodgson (1997, 2006), Potts (2000), Vanberg (2002, 2004), Ostrom (2005), Parra (2005).

${ }^{9}$ See Shleifer and Vishny (1993), Mauro (1995), Jain (2001), Mo (2001), Aidt (2003), Pellegrini and Gerlagh (2004).
} 
Legal institutionalism draws from all these traditions, but gives particular emphasis to the role of the state in the legal system, and to the constitutive role of law in social and economic life. It further emphasizes the importance of understanding the institutional processes of legislation and legal evolution. Accordingly it addresses a series of research questions, including the nature and effect of variations between different legal systems within capitalism.

Above all, legal institutionalism focuses on the legal and political apparatuses of power and legitimation that concern abstract rights, as well as the flows of material goods and services that have preoccupied economists since Adam Smith. Capitalism is much more than material objects and forces, it is a complex system for processing information and allocating and protecting rights to tangible and intangible assets. Understanding all this is vital for appropriate policies for capitalist regulation and development.

\section{Acknowledgments}

We thank Francesca Gagliardi and an anonymous referee for helpful feedback on an earlier version, and the Economic and Social Research Council for financial support (ESRC grant ES/J012491/1, 'Law, Development and Finance in Rising Powers').

\section{References}

Alchian, A.A., 1977. Some implications of recognition of property right transaction costs. In: Brunner, Karl (Ed.), Economics and Social Institutions: Insights from the Conferences on Analysis and Ideology. Boston, MA. Martinus Nijhoff, pp. 234-255.

Aidt, T.S., 2003. Economic analysis of corruption: a survey. Econ. J. 113 (8) November, pp. F632-FF52.

Alchian, A.A., Demsetz, H., 1972. Production, information costs, and economic organization. Am. Econ. Rev. 62 (4), 777-795 December.

Arner, Douglas W., Booth, Charles D., Lejot, Paul, Hsu, Berry Fong Chung, 2007. Property rights, collateral, creditor rights, and insolvency in East Asia. Texas International Law Journal 42, 515-559 August.

Arruñada, B., 2012. Institutional Foundations of Impersonal Exchange: Theory and Policy of Contractual Registries. University of Chicago Press, Chicago.

Aviram, A., 2004. A paradox of spontaneous formation: the evolution of private legal systems. Yale Law Policy Rev. 22 (1), 1-68.

Baker, J.H., 1979. The law merchant and the common law before 1700,. Camb. Law J. 38 (2), 295-322 November.

Benson, B.L., 1990. The Enterprise of Law: Justice Without the State. Pacific Research Institute for Public Policy, San Francisco.

Berman, H.J., 1983. Law and Revolution: The Formation of the Western Legal Tradition. Harvard University Press, Cambridge, MA.

Blair, M.M., 1999. Firm-specific human capital and theories of the firm. In: Blair, M.M., Mark, R. (Eds.), (1999) Employees and Corporate Governance. Brookings, Washington, DC, pp. 58-89.

Blair, M.M., 2003. Locking in capital: what corporate law achieved for business organizers in the nineteenth century. UCLA Law Rev. 51 (2), 387-455.

Blair, M.M., Stout, L.A., 1999. A team production theory of corporate law. J. Corp. Law 24 (4), 751-806.

Blau, P., 1964. Power and Exchange in Social Life. Wiley, New York.

Bradley, J.P., 1902. Miscellaneous Writings of the Late Hon. Joseph P. Bradley. Hardham, Newark, NJ.

Camic, C., Hodgson, G.M. (Eds.), 2011, Essential Writings of Thorstein Veblen. Routledge, London and New York.

Cheung, S.N.S., 1983. The contractual nature of the firm. J. Law Econ. 26 (2), 1-21 April.

Coase, R.H. 1937. The nature of the firm. Economica 4, 386-405 New Series, November.

Coase, R.H., 1988. The Firm, the Market, and the Law. University of Chicago Press, Chicago.

Coleman, J., 1990. Foundations of Social Theory. Harvard University Press. Cambridge, MA.

Commons, J.R., 1924. Legal Foundations of Capitalism. Macmillan, New York.

Crawford, Sue E.S., Ostrom, Elinor, 1995. A Grammar of Institutions. Am. Political Sci. Rev. 89 (3), 582-600 September.

De Soto, H., 2000. The Mystery of Capital: Why Capitalism Triumphs in the West and Fails Everywhere Else. Basic Books, New York.

Deakin, S., 2006. Capacitas: contract law and the institutional foundations of a market economy. Eur. Rev. Contract Law 2 (3), 317-341.

Deakin, S., 2012. The juridical nature of the firm. In: Clarke, T., Branson, D. (Eds.), The Sage Handbook of Corporate Governance. Sage, London, pp. 113-135.

Demsetz, H., 1967. Toward a Theory of Property Rights. Am. Econ. Rev. 57 (2), 347-359.

Diamond, A.S., 1935. Primitive Law. Watts, London.

Doeringer, P.B., Piore, M.J., 1971. Internal Labor Markets and Manpower Analysis. Heath, Lexington, MA.

Dopfer, K., Foster, J., Potts, J., 2004. Micro-Meso-Macro. J. Evolut. Econ. 14 (3), 263-279 July.

Dore, R., 1983. Goodwill and the spirit of market capitalism. Br. J. Sociol. 34 (4), 459-482.

Eccles, R.G., 1981. The quasifirm in the construction industry. J. Econ. Beh. Organ. 2, 335-357.

Ellickson, R.C., 1991. Order Without Law: How Neighbors Settle Disputes. Harvard University Press, Cambridge, MA.

Fuller, L.L., 1967. Legal Fictions. Stanford University Press, Stanford.

Furubotn, E., Pejovic, S., 1972. Property rights and economic theory: a survey of recent literature. J. Econ. Lit. 10 (4), 1137-1162.

Furubotn, E., Pejovic, S. (Eds.), 1974, The Economics of Property Rights, Ballinger. Cambridge, MA.

Gindis, D., 2007. Some building blocks for a theory of the firm as a real entity. In: Yuri, B., Arnaldo, C., Thierry, K. (Eds.), The Firm as an Entity: Implications for Economics, Accounting and Law. Routledge, London and New York, pp. 266-291.

Gindis, D., 2009. From fictions and aggregates to real entities in the theory of the firm. J. Inst. Econ. 5 (1), 25-46 April

Goldberg, V.P., 1980. Relational exchange: economics and complex contracts. Am. Behav. Sci. 23 (3), $337-352$.

Greif, A., 1989. Reputations and coalitions in medieval trade: evidence on the Maghribi traders. J. Econ. Hist. 49 (4), $857-882$ December.

Greif, A., 1993. Contract enforceability and economic institutions in early trade: the Maghribi traders' coalition. Am. Econ. Rev. 83 (3), $525-548$ June.

Greif, A., 1994. On the political foundations of the late medieval commercial revolution: Genoa during the twelfth and thirteenth centuries. J. Econ. Hist. 54 (2), 271-287 June.

Greif, A., 2006. Institutions and the Path to the Modern Economy: Lessons from Medieval Trade. Cambridge University Press, Cambridge and New York.

Greif, A., Milgrom, P., Weingast, B.R., 1994. Coordination, commitment, and enforcement: the case of the merchant guild. J. Political Econ. 102 (4), 745-776 August.

Grossman, S.J., Hart, O.D., 1986. The costs and benefits of ownership: a theory of vertical and lateral integration. J. Political Econ. 94 (4), 691-719 August. Hadfield, G.K., Weingast, B.R., 2012. What is Law? A coordination account of the characteristics of legal order. J. Legal Anal. 42 (2), 471-514 Winter.

Hallowell, A.I., 1943. The nature and function of property as a social institution'. J. Legal Political Sociol. 1 (3-4), 115-138.

Hansmann, H., Kraakman, R., Squire, R., 2006. Law and the rise of the firm. Harv. Law Rev. 119 (5), 1333-1403 March.

Hart, O.D., 1989. An economist's perspective on the theory of the firm. Columbia Law Rev. 89 (7), 1757-1774.

Hart, O.D., 1995. Firms, Contracts, and Financial Structure. Oxford University Press, Oxford.

Hart, O.D., 2011. Thinking about the firm: A review of Daniel Spulber's the theory of the firm. J. Econ. Lit. 49 (1), 101-113.

Hart, O.D., Moore, J., 1990. Property rights and the nature of the firm. J. Political Econ. 98 (6), 1119-1158 December.

Hasnas, J., 2005. Hayek, the common law, and the fluid drive. NYU J. Law Liberty 1, 79-110.

Hayek, F.A., 1973. Law, Legislation and Liberty; Volume 1: Rules and Order. Routledge and Kegan Paul, London. 
Heinsohn, G., Steiger, O., 2013. In: Decker, F. (Ed.), Ownership Economics: On the Foundations of Interest, Money, Markets, Business Cycles and Economic Development. Routledge, London and New York.

Hodgson, G.M., 1997. The ubiquity of habits and rules. Camb. J. Econ. 21 (6), 663-684 November.

Hodgson, G.M., 2002. The legal nature of the firm and the myth of the firm-market hybrid. Int. J. Econ. Bus. 9 (1), 37-60 February.

Hodgson, G.M., 2006. What are institutions? J. Econ. Issues 40 (1), 1-25 March.

Hodgson, G.M., 2009. 'On the institutional foundations of law: the insufficiency of custom and private ordering'. J. Econ. Issues 43 (1), $143-166$ March.

Hodgson, G.M., 2015. Conceptualizing Capitalism: Institutions, Evolution, Future. University of Chicago Press, Chicago.

Hodgson, G.M., Jiang, Shuxia, 2007. The economics of corruption and the corruption of economics: an institutionalist perspective. Journal of Economic Issues 41 (4), 1043-1061 December.

Hoffman, S., 2013. Property, possession and natural resource management: towards a conceptual clarification. J. Inst. Econ. 9 (1), 39-60 March.

Hohfeld, W.C., 1919. Fundamental Legal Conceptions as Applied in Judicial Reasoning, and Other Legal Essays. Yale University Press, New Haven, CT.

Homans, G., 1961. Social Behavior: Its Elementary Forms. Harcourt, Brace, Jovanovich, New York.

Honoré, A.M., 1961. Ownership. In: Guest, A.G. (Ed.), Oxford Essays in Jurisprudence. Oxford University Press, Oxford.

Huntington, S.P., 1968. Political Order in Changing Societies. Yale University Press, New Haven, CT.

Holmström, B., 1999. The firm as a subeconomy. J. Law, Econ. Organ. 15, 74-102.

Iacobucci, E.M., Triantis, G.G., 2007. Economic and legal boundaries of firms. Virginia Law Rev. 93 (3), $515-570$.

Ireland, P.W., 1999. Company law and the myth of shareholder ownership. Modern Law Rev. 62 (1), 32-57 January.

Iwai, K., 1999. Persons, things and corporations: the corporate personality controversy and comparative corporate governance. Am. J. Comp. Law 47 (4), 583-632 Autumn.

Jain, A.K., 2001. Corruption: a review. J. Econ. Surv. 15 (1), 71-120 February.

Jensen, M.C., Meckling, W.H., 1976. Theory of the firm: managerial behavior, agency costs and ownership structure. J.f Fin. Econ. 3 (4), 305-360 October.

Knight, J., 1992. Institutions and Social Conflict. Cambridge University Press, Cambridge.

La Porta, R., Lopez-de-Silanes, F., Shleifer, A., 2008. The economic consequences of legal origins. J. Econ. Lit. 46 (2), 285-332 June.

La Torre, M., 1993. Institutionalism old and new. Ratio Juris 6 (2), 190-201 July.

Landa, J., 1994. Trust, Ethnicity, and Identity: Beyond the New Institutional Economics of Ethnic Trading Networks, Contract Law, and Gift Exchange. University of Michigan Press, Ann Arbor, MI.

Lueck, D., Miceli, T., 2007. Property law. In: Polinsky, A.M., Shavell, S. (Eds.), Handbook of Law and Economics. Elsevier, Amsterdam.

Macaulay, S., 1963. Non-contractual relations in business: a preliminary study. American Sociological Review 28 (1), 1-23.

MacCormick, D.N., 2007. Institutions of Law: An Essay in Legal Theory. Oxford University Press, Oxford and New York.

MacLeod, H.D., 1878. The Elements of Banking, 4th edn Longmans Green, London.

Marx, K., 1971. A Contribution to the Critique of Political Economy, translated from the German edition of 1859. Lawrence and Wishart, London.

Marx, K., 1973. The Revolutions of 1848: Political Writings - Volume 1, edited and introduced by David Fernbach. Penguin, Harmondsworth.

Marx, K., 1975. Early Writings. Penguin, Harmondsworth.

Marx, K., 1976. Capital, 1. Pelican, Harmondsworth , translated by Ben Fowkes from the fourth German edition of 1890.

Masten, S.E., 1991. A legal basis for the firm. In: Williamson, O.E., Winter, S.G. (Eds.), (1991) The Nature of the Firm: Origins, Evolution, and Development. Oxford University Press, Oxford and New York, pp. 196-212.

Mauro, P., 1995. Corruption and growth. Q. J. Econ. 110 (3), 681-712 August.

Ménard, C., 1995. Markets as institutions versus organizations as markets? Disentangling some fundamental concepts. J. Econ. Behav. Organ. 28 (2), 161-182.

Ménard, C., 1996. On clusters, hybrids, and other strange forms: the case of the French poultry industry. J. Inst. Theor. Econ. 152 (1), 154-183 March.

Milgrom, P.R., North, D.C., Weingast, B.R., 1990. The role of institutions in the revival of trade: the law merchant, private judges and the champagne fairs. Econ. Politics 2 (1), 1-23 March.

Mnookin, R.H., Kornhauser, L., 1979. Bargaining in the shadow of the law: the case of divorce. Yale Law J. 88, $950-997$.

Mo, Pak Hung, 2001. Corruption and economic growth. J. Comp. Econ. 29 (1), 66-79 March.

Moore, J., 1992. The firm as a collection of assets. Eur. Econ. Rev. 36 (2-3), 493-507.

North, D.C., 1990. Institutions, Institutional Change and Economic Performance. Cambridge University Press, Cambridge and New York.

North, D.C., Wallis, J.J., Weingast, B.R., 2009. Violence and Social Orders: A Conceptual Framework for Interpreting Recorded Human History. Cambridge

University Press, Cambridge.

Ostrom, E., 2005. Understanding Institutional Diversity. Princeton University Press, Princeton.

Parra, C.M., 2005. Rules and knowledge. Evolut. Inst. Econ. Rev. 2 (1), 81-111 October.

Pejovic, S., 1990. The Economics of Property Rights: Towards a Theory of Comparative Systems. Dordrecht, Kluwer.

Pejovich, S., 1997. The Economic Foundations of Property Rights: Selected Readings. Edward Elgar, Cheltenham.

Penner, J., 1997. The Idea of Property in Law. Oxford University Press, Oxford.

Pellegrini, L., Gerlagh, R., 2004. Corruption's effect on growth and its transmission channels. Kyklos 57 (3), $429-456$.

Phillips, M.J., 1994. Reappraising the real entity theory of the corporation. Fla. State Univ. Law Rev. 21 (4), $1061-1123$.

Pipes, R., 1999. Property and Freedom. Alfred A. Knopf, New York.

Pistor, K., 2013. Towards a legal theory of finance. J. Comp. Econ. published online.

Posner, R.A., 1980. A Theory of Primitive Society, With Special Reference to Law. J. Law Econ. 23 (1), 1-53.

Potts, J., 2000. The New Evolutionary Microeconomics: Complexity, Competence and Adaptive Behaviour. Edward Elgar, Cheltenham.

Richardson, G.B., 1972. The organisation of industry. Econ. J. 82, 883-896.

Robé, J.P., 2011. The legal structure of the firm. Account. Econ. Law 1 (1) Article 5.

Rose-Ackerman, S., 1999. Corruption and Government: Causes, Consequences and Reform. Cambridge University Press, Cambridge and New York.

Samuels, W.J., 1989. The legal-economic nexus. George Washington Law Rev. 57 (6), 1556-1578 August.

Seagle, W., 1941. The Quest for Law. Knopf, New York.

Searle, J.R., 1995. The Construction of Social Reality. Allen Lane, London.

Searle, J.R., 2005. What is an institution? J. Inst. Econ. 1 (1), 1-22 June.

Sened, I., 1997. The Political Institution of Private Property. Cambridge University Press, Cambridge.

Shleifer, A., Vishny, R.W., 1993. Corruption. Q. J. Econ. 108 (3), 599-617 August.

Spulber, D.F., 2009. The Theory of the Firm: Microeconomics with Endogenous Entrepreneurs, Firms, Markets, and Organizations. Cambridge University Press, Cambridge and New York.

Steiger, O. (Ed.), 2008, Property Economics: Property Rights, Creditor's Money and the Foundations of the Economy. Metropolis, Marburg.

Vanberg, V.J., 2002. Rational choice versus program-based behavior: alternative theoretical approaches and their relevance for the study of institutions. Ration. Soc. 14 (1), 7-53 Summer.

Vanberg, V.J., 2004. The rationality postulate in economics: its ambiguity, its deficiency and its evolutionary alternative. J. Econ. Method. 11 (1), 1-29 March. Williamson, O.E., 1975. Markets and Hierarchies: Analysis and Anti-Trust Implications: A Study in the Economics of Internal Organization. Free Press, New York.

Williamson, O.E., 1985a. The Economic Institutions of Capitalism: Firms, Markets, Relational Contracting. Free Press and Macmillan, London and New York. Williamson, O.E., 1985b. Assessing contract. J. Law, Econ. Organ. 1 (1), 177-208 Spring.

Williamson, O.E., 1991. Economic institutions: spontaneous and intentional governance. J. Law, Econ. Organ. 7 (2), $159-187$.

Williamson, O.E., 2007. An interview with oliver Williamson. J. Instit. Econ. 3 (3), 373-386 December. 